\title{
The Well-being of Children and Young People: The Context of Social Services from the Perspective of the Capability Approach
}

\author{
J. Navratilova (Jitka Navratilova), P. Navratil (Pavel Navratil), M. Punova (Monika \\ Punova)
}

Masaryk University, Faculty of Social Studies, Department of Social Policy

Original Article and Social Work, CZ.

\section{E-mail address:}

punova@apps.fss.muni.cz

\section{Reprint address:}

Jitka Navratilova

Masaryk University

Faculty of Social Studies, Department of Social Policy and Social Work

Jostova 10

60200 Brno

Czech Republic

Source: Clinical Social Work and Health Intervention

Volume: 12

Issue: 4

Pages: $49-61$

Cited references: 35

\section{Reviewers:}

Moses Kimon

Nairobi, Kenya

Andrea Shahum

University of North Carolina at Chapel Hill School of Medicine, USA

\section{Keywords:}

Capability Approach. Well-being. Children. Social Services.

\section{Publisher:}

International Society of Applied Preventive Medicine i-gap

CSWHI 2021; 12(4): 49 -61; DOI: 10.22359/cswhi_12_4_06 (C) Clinical Social Work and Health Intervention

\section{Abstract:}

Objective: The aim of this article is to understand how social services contribute to the well-being of children and young people who use them.

Method: The research study, based on Capability Approach, was done using a mixed-research strategy.

Participants: The collection of data took place through 44 indepth semi-structured interviews with children, young people and their parents/foster parents who use social services in one of the regional capitals of the Czech Republic.

Results: Parents at risk underrate their role in loving and caring for their children. Parents at risk are more likely than children 
to undervalue education. Social services do not develop youngsters' capability to live a meaningful life.

Conclusion: The research has shown that although social services have significant potential to ensure well-being for children and youth, they work primarily in a way that provides clients with basic social functioning in the present, without influencing their future positively.

\section{Introduction}

Ensuring the well-being of children is a central motive of governmental measures related to protecting children and safeguarding their rights. The United Nations Convention on the Rights of the Child (The United Nations, 1989) guarantees all children under the age of 18 the observance of their rights and assurance of their best interests (the Czech Republic acceded on 6 February 1991). The state thus becomes the principle guarantor, which, in the spirit of Article 3 of the Convention, "oversees the protection and care necessary for the child's well-being". The Convention has given the child completely new status: the child has become an independent subject of the law, which guarantees respect for the identity of his/her person and the legal right to the assurance of well-being.

Although the notion of child well-being is a common part of legislative practice affecting the work of all those in the area of child protection, its meaning is not absolutely clear, thus leading to a number of difficulties in practice. Various interpretations of child well-being are reflected in diverse concepts of practice, which may pose a certain risk to the social functioning of children and young people.

We believe that reflecting on the concept of child well-being will facilitate at least basic insight into the context of its historical development, which reflects its transformation in the understanding and emphasis that have been attributed to well-being. In brief, the content of child wellbeing has been significantly shaped in society by the "social indicators movement" and "children's rights movement". The UNICEF initiative has been of great importance for the interpretation of child well-being, and has led to the observation of the situation of children in the world, the assurance of their rights and research into their wellbeing. Since 1979, when the first such report, State of the World's Children (Adamson, 2013), was published, there has been a systematic look at the situation of children in the world and how they benefit. Almost 4 decades of systematic interest in the well-being of children has also meant a period of conflicting opinions and expert disputes about which indicators are relevant for measuring child well-being, how they should be measured, and what social policy measures should be implemented. Ben-Arieh (2010a; b), one of the most prominent researchers in the field of child wellbeing, points out, in agreement with Khan \& Kamerman (2009), that in the understanding of child welfare, we have moved from the original notion of rescuing poor and suffering children to the current idea of supporting the development of child well-being. This development reflects the fact that the child is seen as a distinct autonomous being who has his/her being own physical, psychological, spiritual, cultural and social qualities, all of which need to be developed and supported in the interest of the thriving and flourishing of the child (Ben-Arieh et al., 2014).

Emphasis on the well-being of children has also prompted the need to monitor the prosperity of those children whose life situations require specific attention (Gojova et al., 2020; Glumbikova, 2020; Land, 2000; Selwyn \& Briheim-Crookall, 2017; Mydlíková, 2017; Punova, Navratil \& Navratilova, 2000). In light of this goal, we focus our attention to a group of children who are in the care of social services. Based on the research, this article should answer the question: How is well-being developed in children and young people who use social services? In assessing the development of well-being, we refer to the Capability Approach to anchor our theoretical and methodological conceptualization and assess how social services in the selected locality support the development of child wellbeing.

\section{Child well-being and the Capability Approach}

Nowadays, when examining child wellbeing, the Capability Approach (CA), developed 
by Amartya Sen $(1999 ; 1993)$ and Martha Nussbaum (Nussbaum, 2000; 2007), has increasingly been gaining attention. The Capability Approach focuses on the conditions, possibilities and capabilities that enable people to live a life of wellbeing and prosperity. Both authors, who have made a significant contribution to the formulation of the concept of well-being, point out that not every person in society has the same opportunities and freedom of choice to achieve dignified well-being.

Sen's interest in issues of human development and quality of life in the context of existing global inequalities, poverty and famine resulted in the conceptualization of criteria for quality of life and human development, including Human Development Index. The fundamental optics for viewing the functioning of an individual in society include capability, understood as "a varied combination of functioning (ways of being and acting) that a person can achieve. Capability is a set of working vectors reflecting the personal freedom to lead a certain way of life... to choose from possible lives (Sen, 1992). In other words, it is "substantial freedoms that a person uses to lead such a way of life that he/she has reason to appreciate" (Sen, 1999). In Sen's conception, capabilities are perceived as "the ability of an individual to do valuable deeds or to achieve a state of being he/she values" (1993). The decisive factor is, according to Sen, "freedom of choice," which is determined by the structure of the options available to a particular person (1992). In this respect, the notion of capability is essentially a "concept of freedom" reflecting the spectrum of choices that a person has in deciding what kind of life he/she wants to lead (Palovičová, 2011). Different options available to the individual thus lead to different levels of capabilities. These are explained by Sen as the individual peculiarities of individuals, and their cultural and social specificities (1993).

Sen and Nussbaum advocate different approaches to capabilities. Sen's ideas are integral to the participatory development of a person based on the ability of individuals to express and defend, through social dialogue, the minimum degree of capability that would enable such a quality of life that a given society deems as valuable; however, Nussbaum is critical of such an attitude. Her selection of capabilities is founded more as the fulfillment or non-fulfillment of which is an indicator of the existence or non-existence of capabilities. Nussbaum is critical of Sen's assumption that all individuals have the same opportunities to participate in social dialogue and negotiate capabilities allowing them to live the kind of life they could appreciate. For example, people with disabilities point to the fact that there are always individuals in society who are not able to formulate and promote their own rights (Nussbaum, 2007). In contrast to Sen's approach to capabilities, Nussbaum applies a more analytical attitude based on the need for a fairer approach to people who are unable to rationally participate in creating the conditions for the kind of life they could value. In this respect, she has identified 10 basic capabilities she considers to be the foundation for a dignified human life. They are "a set of basic human claims that create a prerequisite for various ways of life; claims that are contained in the idea of human dignity" (1999; 2007).

In the context of the Capability Approach, human well-being is assessed merely by the degree to which an individual achieves the kind of functioning that he/she values. The assessment of human well-being presupposes a distinction between capabilities and human functioning, with "capability meaning only a real opportunity to achieve social functioning in various areas" (Sen et al., 1993). Social functioning itself is a concrete result that the individual has achieved. Palovicova (2011) states that "the difference between capabilities and functioning is, therefore, the difference between the possibility to achieve social functioning and its actual achievement; between the potential and the outcome."

Although Sen and Nussbaum choose different ways of promoting well-being, they agree that society should create fair conditions (for capability) for all, which presupposes taking into account the unique conditions of individuals and their cultural and social contexts. Because of the way the CA is conceptualized, it opens up space for analyzing the physical opportunities that people encounter and their freedoms for achieving a valued way of functioning, as well as making it possible to work with the needs, desires and feelings of individuals. The multi-dimensional character of CA allows us to track several factors simultaneously (Alkire, 2008; Deneulin, 2002). 
Nussbaum's endeavor to have a fair approach to providing conditions for a dignified life, especially for those who have difficulty accessing this, has strong resonance in consideration to child well-being. Arising from a constructivist perspective, the CA approach has thus become one of the pillars of the "conceptual frameworks for understanding the well-being of children" (Biggeri, 2017; Biggeri et al., 2007; Fegter \& Richter, 2014; Navratilova, 2018). This has contributed to the fact that the methodological features of this approach can respond to changes in the way children are perceived which has occurred in the social sciences. Fegter \& Richter (2014) characterize these changes in 3 points: 1 ) the child has become the subject of separate analysis, rather than merely a part of family analysis; 2) there is an increasing focus on the need to explore the diverse areas of children's lives that are important to their everyday life; 3 ) children are increasingly considered to be "experts on their own lives".

Fundamental shifts in perceptions on children and childhood have also had a significant impact on methodology. In contrast to the previous adult-centered perspective applied in the analysis of child well-being, attention has shifted directly to children. Children themselves and their view on how they see their possibilities to realize their own life are now at the heart of the analyses. As such, an autonomous space has opened up for children allowing them to freely and actively participate in shaping their own lives. The child is seen as a distinct social actor; to understand him/her, it is necessary to explore his/her own experiences and ideas (Navrátil, 2019). The Capability Approach allows the understanding of a child's reality not only on his/her individual level, but also takes into account the social context. It is especially the network of relationships between the possibilities that children have and their vision of how they would like to live that can capture the quality of their functioning, or the level of their well-being. This makes it possible to gain a more accurate image of what is important for the child's life from his/her point of view.

\section{Method and study characteristics}

An empirical survey was carried out using a mixed research strategy of semi-structured in- terviews. We created interview scenarios for children and adolescents and their parents / foster parents based on Nussbaum's list of 10 capabilities that are a prerequisite for a dignified life: (1) life; (2) bodily health; (3) bodily integrity; (4) senses, imagination and thought; (5) emotions; (6) practical reason; (7) affiliation; (8) other species; (9) play; (10) control over one's environment [13]. This list of capabilities was updated on the basis of the work of Biggeri et al. (2007) which focuses on the study of capabilities in children.

With regard to finding answers to the main research question (How is well-being developed in children and young people who use social services?), the interview scenario covered 4 main areas that were focused on determining the following: 1) child capabilities; 2) the achieved functioning within the individual dimensions of capability; 3) the impact of the service on the individual dimensions of capability; 4) which aspects of capability the project should prioritize. This scenario enabled the children and young people to determine the most appropriate dimensions of capability and to assess their functioning in light of their ideas of how they would like their life to be. At the same time, it also made it possible to see to what extent the parents consider social services as creating an environment that promotes well-being for their child.

$1^{\text {st }}$, from the point of view of determining the capabilities of children, we identified the following: "What are the most important opportunities that children / young people should have during their lives?" The aim of this question is to find which capabilities (i. e. opportunities) are relevant here, without us limiting the possible responses by a predefined range of options. When the child mentioned a capability that was not previously identified by a researcher, we added the response to the list. When the child mentioned a capability that was already listed, the response was noted. As such, the children directly participated in the formulation of the questionnaire. This phase of interviewing allowed us to conceptualize and identify various capability dimensions.

The $2^{\text {nd }}$ phase of the research was focused on the functioning of the individual capability dimensions that they spoke about in the 1st phase. The children and young people were asked to 
evaluate every capability based on their experience. For example, in regards to the "health" capability, we asked, "Have you been feeling healthy lately?" The result was also noted by the children according to the Lickert scale (1 - lacking; 10 - full health).

In the 3rd phase, we asked the children about what impact the social services had on their capabilities. For this reason, we asked (e.g. in regards to the health capability) "Do you think that the social services you use affect your health or the possibility of living in a healthy way? " The aim of this question was to measure the impact of social services on each identified capability dimension from the subjective view of the children. This question evaluates the expanding or contracting of the capability.

In the $4^{\text {th }}$ last phase of the research, the children were asked what capabilities should be given more attention in social service. Each of the children was questioned about their preferences. The aim is to identify which capabilities the service should pay most attention to. For this reason, we asked, "Which areas of life should the social service pay more attention to in the future?"

Before the implementation of the research, interviewers were trained on the basis of a specially created Interviewer's Manual which included an interview script and remarks sheet. The length of the interview, including filling in of the remarks sheet, ranged from 30-60 minutes, depending on various circumstances, especially the respondent's age; the interview environment; the motivation of the respondent. The conversations were recorded on a Dictaphone, transcribed and then qualitatively interpreted. Selected interview information was also transferred to a remarks sheet containing the list of capabilities, including new ones, so as to make it possible to quantify them all. Scaling techniques have also been used within this strategy. The collected data were processed using IBM SPSS Statistics.

The selection of respondents took place in cooperation with social services organizations thus allowing us to collect data directly from the organization. In total, there were 28 in-depth semistructured interviews with children and young people up to the age of 22 . The average age of the interviewed children and youth was 15.4 years, with the ages ranging from 11-22 years.
For the youth over the age of 18 , we encountered some individuals who continue to make use of social services for youth, despite being over the age limit (of 18).

At the same time, however, we also considered it essential to speak with their parents/foster parents, who have experience with social services and who naturally could evaluate the impact of these services on the children's lives. We conducted 16 interviews with these parents/foster parents: $45 \%$ of which were men; $55 \%$ women. Average age of the interviewed parents was 44.6 years. The youngest parent was 25 ; the oldest 70 (this was the case of a foster grandmother). All participants provided informed verbal consent with their participation in our research.

\section{Results}

In the following section, we present the basic empirical findings related to the evaluation of 4 of the researched areas of capability.

\section{Main areas of potential (opportunities and possibilities)}

Table 1 shows the perspective of children and their parents on what opportunities they consider valuable and essential in order for children to be able to thrive. In order to secure the well-being of their children, parents see as the most important areas: the presence of loving and caring parents (or surrogate parents), and opportunities for learning and health (both $56 \%$ of the parents). A slightly smaller but significant percentage of all the parents (50\%) identified the area of safety; over $77 \%$ of all respondents (children and parents together) agreed with this point.

It seems that the parents want their children to enjoy the commonly held values of health, safety, a family setting and learning opportunities, which are considered in this society to be prerequisites for a successful life. Parents believe that the following are also important for their children: having good relationships (44\%), an open future (38\%), and to have a life free from bullying (31\%).

From the point of view of relationships, it is evident that parents prefer their children to have close family relationships, that is, between child, parents and siblings. Other (more distant) family relationships, and those with friends or within the community are of lower priority. 
Table 1 The importance of individual areas of life from the perspective of children \& parents

\begin{tabular}{|l|rr|rr|}
\hline $\begin{array}{l}\text { Areas } \\
\text { of life }\end{array}$ & \multicolumn{2}{|l|}{$\begin{array}{l}\text { Child/ } \\
\text { Adolescent }\end{array}$} & \multicolumn{2}{l|}{ Parent } \\
\hline & \multicolumn{2}{|l|}{ Count } & \multicolumn{2}{l|}{ Count } \\
\hline Health & 3 & 10.7 & 9 & 56.3 \\
\hline Loving parents & 25 & 89.3 & 9 & 56.3 \\
\hline Siblings & 7 & 25.0 & 4 & 25.0 \\
\hline Relatives & 5 & 18.5 & 3 & 18.8 \\
\hline Friends & 16 & 57.1 & 3 & 18.8 \\
\hline To be feeling fine & 3 & 11.1 & 5 & 31.3 \\
\hline Safety/security & 3 & 10.7 & 8 & 50.0 \\
\hline Good relationships & 12 & 42.9 & 7 & 43.8 \\
\hline $\begin{array}{l}\text { Having personal } \\
\text { opinions }\end{array}$ & 2 & 7.1 & 1 & 6.3 \\
\hline $\begin{array}{l}\text { Chance to learn } \\
\text { new things }\end{array}$ & 4 & 14.3 & 9 & 56.3 \\
\hline $\begin{array}{l}\text { No bullying or } \\
\text { exploitation }\end{array}$ & 3 & 10.7 & 5 & 31.3 \\
\hline $\begin{array}{l}\text { Nice clean } \\
\text { environment }\end{array}$ & 3 & 10.7 & 4 & 25.0 \\
\hline Fun & 4 & 14.3 & 2 & 12.5 \\
\hline Respect & 3 & 10.7 & 4 & 25.0 \\
\hline Spirituality & 1 & 3.6 & 1 & 6.3 \\
\hline Enough time & 3 & 10.7 & 2 & 12.5 \\
\hline Goals & 3 & 10.7 & 3 & 18.8 \\
\hline Going where I want & 3 & 10.7 & 3 & 18.8 \\
\hline Orientation in life & - & - & 4 & 25.0 \\
\hline Open future & 4 & 14.3 & 6 & 37.5 \\
\hline Money & 3 & 14.9 & 1 & 6.3 \\
\hline School & & & 14.3 & 6.3 \\
\hline Work & & & 12.5 \\
\hline Accommodation & & & - \\
\hline
\end{tabular}

It is interesting that parents do not place emphasis on areas that are potential sources of creativity development for their children: such as the ability to express their opinions; have their own goals in life; or form relationships with friends. It seems that parents remain in their parenting "guardian" role and consider the needs of the child only from their point of view. It is clear that the application of an adult-oriented perspective suppresses those areas of children's lives that are important to their development and future.

We analyzed the same question exclusively from the point of view of the interviewed children and young people who use social services and social work services in the city of Brno. The research revealed differences in the viewpoints of the parents and children. The children's views were not so different overall; however, there are some noteworthy differences.

The children and young people assess the importance of the presence of loving and caring parents even more often than the parents. Almost $90 \%$ of them spontaneously stated that the presence of affectionate and caring parents is a very important condition for their well-being. Overall, children and youth are particularly in need of social relationships to be satisfied. Among the most-described conditions for a good life, there are also relations with friends (57\%), good relationships in general (43\%) and relationships with siblings (25\%). In comparison to the parents, some areas of life are not considered as crucial by the children: security (11\%); learning (14\%); respect $(11 \%)$; open future $(14 \%)$. The question is to what extent certain factors play a role in the children's evaluation; for example, they may feel satiated in terms of security and learning, while certain points may be completely irrelevant or even unimaginable for them for the time being.

The research data show the differences between parents' and their children's views of what is important for children to prosper. We consider empirical mapping of these differences to be crucial to confirming the importance of including the perspective of children in a study of child well-being.

\section{Assessing the State of Conditions of Life}

In our research, we also focused on assessing the current state of conditions for child wellbeing. Table 2 shows the average assessment of the state of conditions for child well-being in individual areas of life. The table contains a comparison between the evaluations of the children/youth and parents. We particularly point to those areas where there are noticeable differences between them. The respondents used ratings from 1 to 10 , where 1 is unsatisfactory and 10 is the best possible situation.

Of the areas that were actively evaluated by children, the worst ranked item was Open Future, which rated an average of 3.0 points. Unfortunately, the item Support was also rated 3.0 by children. This item represents formal sources and places of support where children and youth can 
Table 2 State of the individual areas of life from the viewpoints of the children and parents

\begin{tabular}{|l|c|c|}
\hline $\begin{array}{l}\text { Areas } \\
\text { of life }\end{array}$ & $\begin{array}{c}\text { Child } \\
\text { Mean }\end{array}$ & $\begin{array}{c}\text { Parent } \\
\text { Mean }\end{array}$ \\
\hline Health & 9.33 & 9.10 \\
\hline Loving parents & 8.48 & 8.22 \\
\hline Siblings & 9.14 & 10.00 \\
\hline Relatives & 9.00 & 9.67 \\
\hline Friends & 8.50 & 7.33 \\
\hline To be feeling fine & 9.33 & 7.40 \\
\hline Safety/security & 7.33 & 5.57 \\
\hline Good Relationships & 8.33 & 7.43 \\
\hline $\begin{array}{l}\text { Having personal } \\
\text { opinions }\end{array}$ & 7.50 & 8.00 \\
\hline $\begin{array}{l}\text { Chance to learn } \\
\text { new things }\end{array}$ & 4.67 & 6.50 \\
\hline $\begin{array}{l}\text { No bullying or } \\
\text { exploitation }\end{array}$ & 10.00 & 6.75 \\
\hline $\begin{array}{l}\text { Nice clean } \\
\text { environment }\end{array}$ & 9.00 & 10.00 \\
\hline Fun & 6.00 & 7.00 \\
\hline Respect & 10.00 & 10.00 \\
\hline Spirituality & - & 9.00 \\
\hline Community & 9.00 & 7.50 \\
\hline Enough time & 7.67 & 8.67 \\
\hline Goals & 7.67 & 5.33 \\
\hline Going where I want & - & 6.75 \\
\hline Orientation in life & 8.50 & 7.00 \\
\hline Open future & 3.00 & - \\
\hline Money & 8.50 & 8.00 \\
\hline Support & 3.00 & 8.00 \\
\hline School & 8.00 & 10.00 \\
\hline Work & 9.25 & 10.00 \\
\hline Accommodation & 10.00 & - \\
\hline Money & 7.50 & 7.33 \\
\hline Special Education & 10.00 & - \\
\hline Decent education & - & 10.00 \\
\hline Social worker & 10.00 & - \\
\hline
\end{tabular}

turn when in need. It is not clear whether this reflects an inadequacy in their knowledge of available possibilities, or whether there is an actual absence of support. In either case, however, this is a serious finding that requires action. The overall average of the status of Support (including the rating by parents) was higher. Thus, parents assess the possibilities of formal support more positively. It is likely that they have a positive expe- rience with the provision of this support.

The item regarding a chance to learn new things was rated somewhat better. Nevertheless, the state of this condition was assessed by children and young people as below average (4.67). Even here, children express a more critical assessment than that of their parents, who rated it at 6.50 on average. In contrast, the research shows that children rate various items less critically than their parents: for example: their safety; their idea of feeling fine; their feeling of belonging in the community; social services helping them achieve their goals. From the point of view of children, it is evident that social services are not only a source of safety and protection, but also development. It is interesting, however, that children are unable to associate this support to ideas about their future. It seems that children primarily appreciate their present state without linking it to their future.

There is a serious gap in the ways that parents/foster parents and children/youth assess the areas of life. This shows that understanding the child as a client should also be sought in the effort to design adequate services; not just the opinions and experiences of parents are important (but neither should they be underestimated). It is evident that we need to talk openly with children about their future and explicitly about how to achieve a successful future.

\section{The impact of services on the state of opportunities for children from the perspective of children and parents}

In the research, we looked at how respondents perceive the impact of social services and social work services on individual areas of life that are important for the well-being of children and youth. Table 3 shows the average ratings of service impact according to the respondents' ratings, especially the comparisons between the parents and children. As in the previous case, the respondents worked with a scale of 1-10, with a score of 1 being a bad influence and an evaluation of 10 being the best possible impact.

In general, children and young people who have participated in the research evaluate the benefits of the services mainly on the positive side of the scale. Values exceeding 5 can be considered as an assessment of benefit. The children negatively evaluated only the area of finance (av- 
Table 3 The impact of services on individual areas of life from the perspective of children and parents

\begin{tabular}{|l|c|c|}
\hline $\begin{array}{l}\text { Areas } \\
\text { of life }\end{array}$ & $\begin{array}{c}\text { Child } \\
\text { Mean }\end{array}$ & $\begin{array}{c}\text { Parent } \\
\text { Mean }\end{array}$ \\
\hline Health & 5.70 & 5.86 \\
\hline Loving parents & 6.22 & 7.50 \\
\hline Siblings & 8.00 & 7.25 \\
\hline Relatives & 6.00 & 7.33 \\
\hline Friends & 8.13 & 6.67 \\
\hline To be feeling fine & 8.00 & 8.00 \\
\hline Safety/security & 9.67 & 9.29 \\
\hline Good relationships & 8.10 & 9.00 \\
\hline $\begin{array}{l}\text { Express personal } \\
\text { opinions }\end{array}$ & 9.00 & 9.00 \\
\hline $\begin{array}{l}\text { Chance to learn } \\
\text { new things }\end{array}$ & 0.75 & 8.56 \\
\hline $\begin{array}{l}\text { No bullying or } \\
\text { exploitation }\end{array}$ & 6.00 & 7.80 \\
\hline $\begin{array}{l}\text { Nice clean } \\
\text { environment }\end{array}$ & 9.33 & 9.50 \\
\hline Fun & 8.75 & $7 . .0$ \\
\hline Respect & 6.33 & 9,25 \\
\hline Spirituality & 7.00 & 10.00 \\
\hline Community & - & 9.00 \\
\hline Enough time & 5.33 & 10.00 \\
\hline Goals & 7.33 & 10.00 \\
\hline Going where I want & 8.33 & 7.33 \\
\hline Orientation in life & - & 8.75 \\
\hline Open future & 7.00 & 8.00 \\
\hline Money & 4.00 & 6.50 \\
\hline Support & 7.00 & - \\
\hline School & 8.25 & 7.50 \\
\hline Work/Job & 7.00 & - \\
\hline Accommodation & 3.00 \\
\hline Free-time activities & 10.00 \\
\hline Decent education & \\
\hline
\end{tabular}

erage 4). However, this result can be understood as meaning that social services do not allow young people to earn money.

Services are valued for their contribution as a source of support (average rating 10). They are perceived by children to provide safety and security (9.67), as well as a nice clean environment (9.33). The services are also highly valued for providing opportunities for expressing and cultivating personal opinions (9), as well as creating and offering leisure time facilities (fun 8.75). The services expand their clients' possibilities in the area of spatial mobility (8.33) and increase their chances of obtaining a job (8.25). Children also perceive that the services increase their possibilities for an open future (7). It is evident that the potential of social services to help provide a better future for children is great and that children also perceive it. It is a challenge for social services to exploit this potential, because the unfortunate data showing little hope of an open future for children in the care of social services may point to unused resources. It is also worth mentioning that, according to children's assessments, the services are not able to influence the provision of loving and caring parents. The average rating in this area is 6.22 . We believe that it would be worthwhile to consider whether and how the focus of services can be developed and strengthened in the future. It is evident that the development of parental competences of the parents/foster parents would be appreciated by the children in the study.

From the perspective of parents there is a better evaluation primarily in the area of relationships, especially between themselves and their children, and between relatives and children. Compared to children, parents give a lower rating to the impact of services on sibling and friend relationships. Compared to children, parents give a significantly higher rating to the amount of free time. This difference is worth noting because, as other research shows, the nature of free-time activities affects children's well-being (The Children's Society, 2017).

\section{The development of social services in terms of capabilities}

In this section, we asked about which conditions of life should be given more attention in the context of social services and social work services. We asked children and parents about their preferences for future service delivery. The aim is to identify the most important conditions that service providers should pay increased attention to. The areas of life are judged on a scale of 110 , where 1 has the least importance for service development and 10 has maximum importance.

The average values, which respondents assigned according to the importance of individual areas of life for service development, are presented as a comparison between parents and chil- 
Table 4 Development of services with respect to individual areas of life from the perspective of children and parents

\begin{tabular}{|l|c|c|}
\hline $\begin{array}{l}\text { Areas } \\
\text { of life }\end{array}$ & $\begin{array}{c}\text { Child } \\
\text { Mean }\end{array}$ & $\begin{array}{c}\text { Parent } \\
\text { Mean }\end{array}$ \\
\hline Health & 4.50 & 4.22 \\
\hline Loving parents & 6.40 & 5.11 \\
\hline Siblings & 5.00 & 3.75 \\
\hline Relatives & 5.67 & 4.33 \\
\hline Friends & 7.43 & 6.67 \\
\hline To be feeling fine & 8.33 & 5.25 \\
\hline Safety/security & 10.00 & 7.29 \\
\hline Good relationships & 6.80 & 6.14 \\
\hline $\begin{array}{l}\text { Having personal } \\
\text { opinions }\end{array}$ & 6.50 & 9.00 \\
\hline $\begin{array}{l}\text { Chance to learn } \\
\text { new things }\end{array}$ & 7.50 & 7.89 \\
\hline $\begin{array}{l}\text { No bullying or } \\
\text { exploitation }\end{array}$ & 3.67 & 6.40 \\
\hline $\begin{array}{l}\text { Nice clean } \\
\text { environment }\end{array}$ & 4.67 & 10.00 \\
\hline Fun & 7.50 & 5.50 \\
\hline Respect & 5.33 & 4.75 \\
\hline Spirituality & 5.00 & 1.00 \\
\hline Community & - & 2.00 \\
\hline Enough time & 6.00 & 1.00 \\
\hline Goals & 5.33 & 7.00 \\
\hline Going where I want & 9.50 & 9.67 \\
\hline Orientation in life & - & 7.75 \\
\hline Open future & 5.00 & 9.80 \\
\hline Money & 5.00 & 8.00 \\
\hline Support & 2.00 & 10.00 \\
\hline School & 4.33 & 9.00 \\
\hline Work & 7.33 & - \\
\hline Accommodation & 5.00 & - \\
\hline Car & - & 500 \\
\hline Education & 4.00 \\
\hline Free-time activities & \\
\hline Decent education & -00 \\
\hline
\end{tabular}

dren/youth who participated in the interviews (Table 4).

In terms of future service development, the priorities for children and youth included: safety/security (average 10); spatial mobility (9.5); emotional well-being (8.33); development of knowledge and skills (7.5); leisure-time activities. It is worth noting that parents' ratings for safety/security and mental/emotional well-being appear to be less significant (7.29). However, the views of children here reflect some criticism.

Another 5 areas that children and young people proposed as important for the future targeting of services range in average values from 6.04 to 7.43. This area has unambiguously subjective weight given to the topics; however, the data should also be taken into account in future strategies for service development. The topics include: relationships with friends (average value 7.43); the issue of temporary/permanent housing (7.33); the topic of relationships (6.80); the area of expression and cultivation of personal opinions (6.5); as well as the sphere of support for parental competence (6.04).

When we look at the priorities for service development with respect to the opinions of parents, other important topics appear. The following topics were in the highest positions: a nice clean environment (average 10); raising children to be decent (10); with emphasis on services helping to provide an open future for the children $(9,80)$; as well as a focus on helping children/youth to gain good orientation in life $(7,75)$. It is interesting that in contrast to parents' high rating, children themselves support the development of services in the area of an open future at a value of 6 , which is slightly higher than average.

\section{Discussion}

The main objective of this article was to understand to what extent social services enable children and young people to improve their wellbeing. The research, anchored in the theory of capability, not only examines whether social services create conditions for children to prosper, but also shows an image of what children themselves consider as important for achieving their own well-being. In order to better understand what children in the care of social services need, we are taking into consideration results obtained and their interpretations in the context of other research studies involvingsubjective measurement of child well-being (Selwyn \& Briheim-Crookall, 2017; The Children's Society, 2017).

These studies, like ours, have shown the crucial role of relationships in children's lives. The success of children and young people in relationships with peers and others is crucial. According to research (Richardson et al., 2008; Selwyn \& 
Briheim-Crookall, 2017; Vysloužilová \& Navrátil, 2019), these relationships influence children in the perception of themselves as social actors and generally affect the level of their life satisfaction. For children in our group, this means primarily the relationships with parents, whether biological or surrogate. This is closely followed by relationships with friends. For children, the importance of relationships with others is greater than for their parents, although even the parents consider them to be crucial.

In the context of relationships and their fundamental position in children's lives, we should pay increased attention to their development. A comparative study of the Children's Society (The Children's Society, 2017) has produced strong evidence that the quality of these relationships is deteriorating. From 2009 to 2015, there was a decline noted in the level of happiness in relationships with friends and in life generally. Although this trend was observed in British children and young people, an annual comparative study by UNICEF on the situation of children in the world also reflects this fact. For the Czech Republic, this trend is even more pronounced. According to the above UNICEF study, conducted in April 2013, the Czech Republic has the lowest values of all the countries of Central and Eastern Europe in the quality of children's relations $\left(26^{\text {th }}\right.$ place). Only $56 \%$ of Czech children consider their classmates to be "nice and considerate". This rating is one of the lowest in the developed world (Adamson, 2013). In this respect, it seems essential to create within the framework of social services conditions that promote good relations and at the same time prevent risky forms of relationship development. This does not concern only the prevention of bullying, but mainly the prevention of arguing and fighting among children. According to this UNICEF report, Czech children are among the highest in the level of conflict among peers.

A more positive point is that social services are seen as a means for helping children and youth to become incorporated into a network of relationships. However, a certain risk can be seen in the fact that social services do not focus on the development of these relationships. The possibility for building interpersonal relationships has arisen as a natural consequence of the fact that social services are, used by other people through whom the children and youth are drawn into a network of relationships. An active approach to developing this capability could in many ways result in increased success in children's lives. For example, the results of a research study (Selwyn \& Briheim-Crookall, 2017) have shown that in order to fulfill the well-being of children in care, it is crucial for the child to have at least one key adult available. Thanks to such a relationship, many skills and abilities develop that are important for the child to mature, and are prerequisites for a successful life.

Perhaps the most serious observation brought about by this research is the perceived lack of hope for the future of the children using social services. The results of the research have shown that skepticism regarding the child's future outweighs optimism and hope. The research findings show that children and young people in social services do perceive that these services affect their future; however, they do not expect them to be a means to help contribute to a promising future.

It has often been shown that hope is an important part of such life prospects, enabling people to actively participate in personal and social life (Matejcek, 1999). It is interesting that the studies in the UK (Selwyn \& Briheim-Crookall, 2017) are generally consistent with the results of our studies, although there is one fundamental difference: the British children living in surrogate family care, unlike the Czech children, see hope for the future. This is an alarming fact that cannot be easily resolved and deserves proper attention. These results represent a great challenge for social workers working with these children. It is evident that the mere factual existence of certain capabilities is no guarantee that children will be able to use them; , that they will be able to perceive certain potential as meaningful for turning it into a result.

From the point of view of capability approaches, through which we view the well-being of children, it seems to be appropriate to develop services that, instead of merely ensuring material well-being, are consciously aimed at developing the physical, mental, emotional, spiritual, cultural and social characteristics of children, as essential prerequisites for the development and promotion of their well-being. A prerequisite for this development of social services is the education of so- 
cial workers, which develops their professionalism (Navratilova \& Navratil, 2020; Punova, 2019; 2020)

\section{Conclusion}

In this research on the prosperity of children using social care services, we have used a research tool based on the Capability Approach. With this study, we also wanted to discover whether it is appropriate to use this tool to explore the well-being of children and young people in the Czech environment of social services.

Experience from the research has shown that tools based on the Capability Approach were accepted without difficulty by children. Our young respondents actively participated in identifying capabilities that they considered important for their lives. The involvement of children in the research design was also facilitated by the fact that one of the important components of this approach is the emphasis on the individual experience; wishes and aspirations of the people interviewed. It is particularly the emphasis on these characteristics of life that became an important factor of their active participation in the research.

We believe that in using this tool, we have gained significant findings about the lives of these children and young people using social services. We consider the findings that point to the absence of hope in the lives of the children to be particularly serious. We believe that this requires special attention and for us to consider whether the childcare system itself does not create dispositions for the absence of hope for the future of children and young people. We believe that focusing primarily on material conditions may help children to live better in the present; however, this approach may not positively affect their future. For this reason, we believe that there is a need to make significant changes to the childcare system to ensure their well-being. One of the most important changes we see is that we should seriously consider how to invite children and young people to participate in creating their own concept of well-being. We should allow ways for them to participate with regard to their own development and source of freedom.

Although our research has not captured the reason why children in the care of social services do not look to their future with hope, other studies show that active participation of children in determining their own life opens a space in which they learn to take responsibility for their lives and exploit potential of their creativity. These abilities are also important in the prevention of risky phenomena such as bullying, addiction and other pathological behavior in children (Giant, 2014; Navratilova, 2015). They are also the basis for children and young people to develop resilience for surviving in difficult life situations (Ruzickova \& Punova, 2018).

Research on child well-being has brought many challenges to the conceptualization of social services. We believe that within these concepts, we should create a space for involving children and youth in determining the form of what is offered by these services. Although the services are conceived on the basis of community planning (which means there is an opportunity to involve the users of the services), it is still only dult-oriented perspective that is considered. Not only are children uninvolved in the process of negotiation about the form of these services, but this possibility is not even considered.

From the perspective of the content of the service offer, it is clear that certain services are absent; such services involving capabilities that would help children learn practical ways of how to live responsibly in society. Practical experience from the field shows that "overloading the client with services" leads to client dependence on services as well as a low level of responsibility for their lives. Within these services, children and young people should have the opportunity to engage responsibly in the resolution of their life situations.

Furthermore, the offer of social services pays very little attention to existentially sensitive topics such as child identity, their self-development and using their potential for their current and future functioning. The absence of these topics can also be a source of some uncertainties: low selfesteem and disorientation as to who they are and who they would like to be. This could also be a source of the low degree of hope for the future that the children/youth expressed in the survey.

Attention that is dedicated to children and young people who are being helped by professionals is mainly seen from the perspective of securing their rights and fulfilling their needs. Although respecting children's rights and providing for their needs play a key role in their protection, 
we do not place enough emphasis on the aspect of prosperity which relates to the high quality living of one's own life. We believe that there is a need within the offer of services to steer slightly away from the perspective of securing children's rights and needs - towards one of supporting their reflective capabilities to handle life. Today's late-modern times require new types of skills: children and young people need to learn to cooperate with others; to negotiate and to have dialogues. They need to learn how - in an uncertain world - to build their own successful existence.

\section{References}

1. AMSON P (2013) Child well-being in rich countries: A comparative overview. United Nations Publications.

2. ALKIRE S (2008) Choosing dimensions: The capability approach and multidimensional poverty. Palgrave Macmillan.

3. BEN-ARIEH A (2010a) Developing indicators for child well-being in a changing context. In ROSE W \& MCAULEY C (Eds), Child well-being: Understanding children's lives (pp.129-142). Jessica Kingsley Publishers.

4. BEN ARIEH A (2010b) From child welfare to children well-being: The child indicators perspective. In KAMERMAN S B, PHIPPS $\mathrm{S} \&$ BEN-ARIEH A (Eds), From child welfare to child well-being: An international perspective on knowledge in the service of policy making children's well-being: Indicators and research series, vol. 1. (pp.9-22). Springer.

5. BEN ARIEH A, CASAS F, FRONES I \& KORBIN J E (2014) Multifaceted concept of child well-being. In BEN-ARIEH A, CASAS F, FRONES I \& KORBIN J E (Eds.), Handbook of Child Well-Being Handbook of child well-being (pp. 1-27). Springer The Netherlands.

6. BIGGERI M (2017) Children and the capability approach. Palgrave Macmillan.

7. BIGGERI M, LIBANORA R, MARIANI S \& MENCHINI L (2007) Children conceptualizing their capabilities: Results of a survey conducted during the first Children's World Congress on Child Labor. J. of Human Development, 7(1), 59-83.

8. DENEULIN S (2002) Perfectionism, paternalism and liberalism in Sen and Nussbaum's capability approach. Review of Political Economy, 14(4), 497-518.

9. FEGTER S \& RICHTER M (2014) Capability approach as a framework for research on children's well-being. In BEN-ARIEH A, CASAS F, FRONES I \& KORBIN J E (Eds.), Handbook of child well-being (pp. 739-758). Springer Netherlands.

10. GIANT N (2014) Life coaching for kids: a practical manual to coach children and young people to success, well-being and fulfilment. Jessica Kingsley publishers.

11. GLUMBÍKOVÁ K (2021) Non-normative use of reflexivity in social work with families in the Czech Republic. British Journal of Social Work, 51(2), 583-599.

12. GOJOVA A, GRUNDELOVA B, CILECKOVA K \& CHRENKOVA M (2020) Path toward a Child-Centered Approach in the Czech Social and Legal Protection of Children. Sustainability, 12(2), s. 1-18.

13. KHAN A J (2009) From child saving to child development. In KAMERMAN S, PHIPPS $\mathrm{S} \&$ BEN-ARIEH A (Eds.), From child welfare to child well-being: An international perspective on knowledge in the service of policy making (pp. 3-8). Springer Netherlands.

14. LAND K C (2000) Social Indicators. In BORGATTA E F \& MONTGOMERY R J $\mathrm{V}$ (Eds.), Encyclopedia of sociology (pp. 2682-2690). Macmillan.

15. MATEJCEK Z (1999) Surrodate Family Care - A guide for professionals, adopters, and fosters parens. Portal.

16. MYDLIKOVA E (2017) Indicators for Assessing Children from Socially At-risk Families. The European Journal of Social \& Behavioural Sciences, 10(3), 2468-2475.

17. NAVRATIL P (2019) Epistemic discourses of 'explanation' and 'understanding' in assessment models. In PAYNE M \& REITH-HALL E (Eds.). The Routledge Handbook of Social Work Theory. (pp. 69-83). Routledge.

18. NAVRATILOVA J (2015) Life coaching as a means to build the identity of young people. INPROFORUM: Common challenges - different solutions - mutual dialogue. University of South Bohemia in Ceske Budejovice.

19. NAVRATILOVA J (2018) Use of capability approach in assessing children's well being. Social work., 18(6), 65-77. 
20. NAVRATILOVA J \& NAVRATIL P (2020) The concept of professional identity in selected approaches to the education of social workers. In SAJID S M, BAIKADY R, SHENG-LI C \& SAKAGUCHI H (Eds.), The Palgrave Handbook of Global Social Work Education. (pp. 133-150). Palgrave Macmillan.

21. NUSSBAUM M (1999) Women and equality: The capabilities approach. International Labour Review, 138(3), 227-245.

22. NUSSBAUM M C (2000) Women and human development: the capabilities approach. Harvard University Press.

23. NUSSBAUM M C (2007) Frontiers of justice: disability, nationality, species membership. Harvard University Press.

24. PALOVICOVA Z (2011) The concept of social functioning. Philosophy, 66(9), 833-844.

25. RUZICKOVA J \& PUNOVA M (2018) Accompanying scout members in difficult life situations. Social work, 18(2), 85-101.

26. PUNOVA M (2019) Strengthening resilience in the practical education of social work students. Social work, 9(2), 5-20.

27. PUNOVA M (2020) Personality disposition and resilience of social workers. Social work, 20(5), 88-107.

28. PUNOVA M, NAVRATIL P \& NAVRATILOVA J (2020) Capabilities and well-being of child and adolescent social services clients in the Czech Republic. Children and Youth Services Review, 117, 1-9.

29. RICHARDSON D, HOELSCHER P \& BRADSHAW J (2008) Child well-being in central and eastern european countries $(C E E)$ and the Commonwealth of independent states (CIS). Child Indicators Research, 1(3), 211-250.

30. SELWYN J \& BRIHEIM-CROOKALL L (2017) Our Lives Our care: Looked after children's views on their well-being. University of Bristol.

31. SEN A K (1992) Inequality reexamined. Russell Sage Foundation.

32. SEN A K (1999) Development as Freedom. Oxford University Press.

33. SEN A K, NUSSBAUM M C \& World Institute for Development Economics, R. (1993). The Quality of Life. Clarendon Press.

34. The Children's Society (2017). The Good
Childhood Report. Society, T. C. s. The United Nations (1989). Convention on the Rights of the Child.

35. VYSLOUZILOVA A \& NAVRATIL P (2019) Individualization in social work with the family - blaming the victims. Social work, 19(6), pp.142-157. 